\section{RICYDE. Revista Internacional de Ciencias del Deporte doi: $10.5232 /$ ricyde \\ Rev. Int. cienc. deporte}

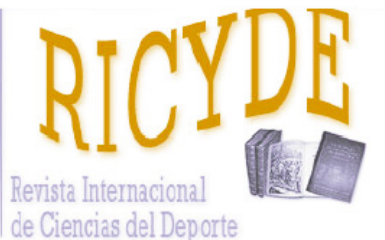

RICYDE. Revista Internacional de Ciencias del Deporte Volume XV - Year XV

Pages: 284-294 - ISSN: 1885-3137 Issue 57 - July 2019

\title{
Role of emotional intelligence on rock climbing performance El rol de la inteligencia emocional en el rendimiento en escalada
}

\author{
Inmaculada Garrido-Palomino ${ }^{1}$ \& Vanesa España-Romero',
}

1. MOVE-IT Research group and Department of Physical Education, Faculty of Education Sciences University of Cádiz, Cádiz, Spain.

2. Biomedical Research and Innovation Institute of Cádiz (INiBICA). Research Unit, Puerta del Mar University Hospital University of Cádiz, Spain

\begin{abstract}
Purpose: To investigate the association between emotional intelligence (EI) and self-reported climbing ability. Methods: Redpoint climbing ability was used as an indicator of rock climbing performance and EI were assessed as ability and a trait using two different questionnaires MSCEIT and SSEIT in forty-three climbers (15 females and 28 males). ANOVA was used to analyse differences between male and female and advanced and elite climbers in EI parameters in both questionnaires. The analyses were also adjusted by age using ANCOVA. Results: Linear regression analysis revealed that there are no differences between trait EI and climbing performance, but we found the component 'Facilitation Thought' of EI measured as ability was inversely associated with the highest red-point ability. Conclusion: Our results suggest that elite climbers do not use their emotions to facilitate thinking as much as expert climbers, which is positively related to performance. Future researches should direct to investigate how elite climbers manage their emotions.
\end{abstract}

Key words: MSCEIT; SSEIT; emotions; trait; climbing ability.

\section{Resumen}

Objetivo: Investigar la asociación entre la inteligencia emocional (IE) y el nivel de escalada autoinformada. Método: Se usó el nivel de escalada ensayado como un indicador del rendimiento de la escalada en roca y se evaluó en cuarenta y tres escaladores (15 mujeres y 28 hombres) la IE como habilidad tanto como rasgo, utilizando dos cuestionarios diferentes MSCEIT y SSEIT. Se utilizó un ANOVA para analizar las diferencias entre los escaladores masculinos y femeninos y avanzados y élite en los parámetros de IE en ambos cuestionarios. Los análisis también se ajustaron por edad utilizando un ANCOVA. Resultados: El análisis de regresión lineal reveló que no hay diferencias entre el rasgo IE y el rendimiento en escalada, pero encontramos que el componente 'facilitación del pensamiento' de IE como habilidad estaba inversamente asociado con un mayor nivel de escalada ensayada. Conclusión: Nuestros resultados sugieren que los escaladores de élite no usan sus emociones para facilitar el pensamiento, en relación con los escaladores expertos, lo que se relaciona positivamente con el rendimiento. Las investigaciones futuras deben dirigirse a investigar cómo los escaladores de élite manejan sus emociones.

Palabras clave: MSCEIT; SSEIT; emociones; rasgo; nivel de habilidad de escalada.

Correspondencia/correspondence: Inmaculada Garrido-Palomino Department of Physical Education, School of Education, University of Cadiz, Spain Email: inmapsic@hotmail.com 
Garrido-Palomino, I., \& España-Romero, V. (2019). Role of emotional intelligence on rock climbing performance. RICYDE. Revista internacional de ciencias del deporte. 57(15), 284-294.

\section{Introduction}

Q port climbing is a complex sport, with success determined by a combination of technical,

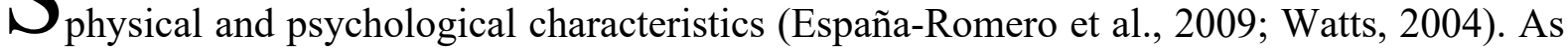
such, due to the sports multifaceted nature, examining the individual contribution of physiological and psychological determinants to sport climbing performance is challenging. Much of the previous literature has focused on physiological mechanisms, and determinants of sport climbing (España Romero et al., 2009; España-Romero et al., 2009; España-Romero et al., 2012; Watts, 2004). Although success or failure in sport rock climbing has been suggested to rely heavily on the psychological state of the performer, there remains a dearth of research investigating these demands, particularly cognitive behaviour (Aras \& Akalan, 2014; Bourdin, Teasdale, \& Nougier, 1998; Green \& Helton, 2011; Hardy \& Jackson, 1996; Hodgson et al., 2009; Nieuwenhuys, Pijpers, Oudejans, \& Bakker, 2008).

In climbing performance context, the psychological characteristics that might contribute to sport climbing success have been studied (Aşçi, Demirhan, \& Dinç, 2007; Pijpers, J., Oudejans, R. R., Bakker, F. C., \& Beek, 2006; Pijpers, Oudejans, \& Bakker, 2005; Sanchez, Boschker, \& Llewellyn, 2010; Sarrazin, Roberts, Cury, Biddle, \& Famose, 2002). Aşçi et al., (2007) suggested that psychological characteristics such as sensation seeking, physical selfperception and extrinsic-intrinsic motivation of climbers were not related to the difficulty of routes ascended by climbers. However, literature points out other psychological variables that might be related to climbing performance. These variables are achievement goals, perceived ability (Sarrazin et al., 2002) and anxiety (Pijpers et al. 2006; Pijpers, Oudejans, \& Bakker, 2005; Sanchez, Boschker, \& Llewellyn, 2010). Nevertheless, not all of those psychological variables seem to affect in the same way. Specifically, task focused achievement goals and perceived ability seemed to have a positive relationship with climbing performance while that ego focused achievement goals and anxiety were reported as disrupt in the climbers' performance. Among those variables, the effect of anxiety on climbing performance has been specially studied. This effect is evidenced by increases both in climbing time (Pijpers et al., 2005; Sanchez et al., 2010) and the number of exploratory movements, as well as longer time periods holding handholds, and slower movements (Pijpers et al., 2005). Conversely, anxiety may play a different role for some climbers producing an improvement in performance, as suggested by the theory of information processing efficiency (Calvo \& Eysenck, 1992). Thus, Hardy \& Hutchinson, (2007) reported that increased anxiety may be associated with increased effort and improved or sustained performance. Further, Sanchez et al., (2010) reported that pre-performance somatic anxiety could be a trait that provides elite climbers with superior performance, and not one that is detrimental.

Emotions, like anxiety, are present in sport climbing, affecting individual performance and ultimately success and failure (Robazza, Bortoli, \& Nougier, 1998). In sport psychology, the concept of emotional intelligence (EI), proposed by Salovey \& Mayer, (1990), could explain the process through which people recognise which emotions appear to help performance and which emotions might hinder performance. Although the ability of athletes to recognise, control and manage their emotions during sport climbing may influence sport climbing performance, it has not been examined yet. In mainstream sports such as baseball and cricket, studies have observed a relationship between EI and performance (Crombie et al., 2009; Zizzi, Deaner, \& Hirschhorn, 2003). Therefore, if the EI of sport rock climbers is related to performance, then it could be that it is an important psychological component, which could be integrated into training programs in order to enhance overall performance. As such, the aim of the study was to examine EI in a range of different ability sport rock climbers. 
Garrido-Palomino, I., \& España-Romero, V. (2019). Role of emotional intelligence on rock climbing performance. RICYDE. Revista internacional de ciencias del deporte. 57(15), 284-294.

\section{Methods}

\section{Participants}

Forty-three experienced sport climbers (15 female and 28 males) aged 18 - 44 years old from Spain volunteered to participate. Climbing experience (yrs), frequency of climbing practice (days per week) and self-reported climbing ability (in accordance with Draper et al., (2011) are presented in Table 1 by gender and climbing ability.

Climbing ability was reported by the most difficult route completed without falls, without inspection or prior knowledge (called onsight climbing) and the most difficult route ascended (without fall or weighting the rope) after having had practice of the route (called redpoint climbing).

Following a comprehensive verbal description of the nature and purpose of the study, written informed consent was obtained. The study protocol was performed in accordance with the ethical standards established in the 1961 declaration of Helsinki and was approved by the Research Ethics Committee from our University.

Table 1. Descriptive Characteristics of the Study Sample

\begin{tabular}{lcccc}
\hline & Male & Female & Expert & Elite \\
& $(\mathrm{n}=28)$ & $(\mathrm{n}=14)$ & $(\mathrm{n}=27)$ & $(\mathrm{n}=15)$ \\
\hline Age (yrs) & $32.8 \pm 6.6$ & $38.0 \pm 3.6^{* *}$ & $33.8 \pm 6.9$ & $35.3 \pm 5.4$ \\
Weight (kg) & $68.2 \pm 6.5$ & $55.2 \pm 5.0^{* *++}$ & $64.8 \pm 8.9$ & $62.2 \pm 7.7$ \\
Height (cm) & $173.7 \pm 7.6$ & $164.8 \pm 4.7^{* *++}$ & $171.4 \pm 8.0$ & $169.5 \pm 7.8$ \\
Climbing experience (yrs) & $11.2 \pm 7.5$ & $11.7 \pm 5.9^{++}$ & $10.3 \pm 6.2$ & $12.8 \pm 8.5^{++}$ \\
Climbing frequency (days per week) & $3.6 \pm 1.3$ & $2.8 \pm 1.0$ & $3.2 \pm 1.2$ & $3.7 \pm 1.3$ \\
Onsight climbing performance & $2.6 \pm 0.7$ & $2.0 \pm 0.5^{*+}$ & $2.0 \pm 0.4$ & $3.2 \pm 0.5^{* *++}$ \\
Redpoint climbing performance & $7 \mathrm{a}+$ & $6 \mathrm{c}^{*+}$ & $6 \mathrm{c}$ & $7 \mathrm{c}^{* *++}$ \\
\hline
\end{tabular}

** $\mathrm{P}<0.001$ and $* \mathrm{P}<0.05$ differences between male and female or expert and elite climbers group

$\uparrow \uparrow \mathrm{P}<0.001$ and $\uparrow \mathrm{P}<0.05$ differences between male and female or expert and elite climbers adjusted by age

\section{Emotional Intelligence measurements}

Emotional Intelligence was measured by two different scales, the Mayer-Salovey-Caruso Emotional Intelligence Test (MSCEIT) (Mayer, Salovey, Caruso, \& Sitarenios, 2003), measuring EI as an ability; and the Schutte Self Report Emotional Intelligence Test (SSEIT) (Schutte et al., 1998) measuring EI as a trait.

The MSCEIT is an ability-based measure that uses two areas (Experimental and strategic EI) to assess each of the four factors of EI (Perceiving and Identifying, Using, Understanding, and Managing Emotions). The questionnaire is made up by 141 items according to the theoretical 
Garrido-Palomino, I., \& España-Romero, V. (2019). Role of emotional intelligence on rock climbing performance. RICYDE. Revista internacional de ciencias del deporte. 57(15), 284-294.

model of Mayer and Salovey, (1997). Separate scores for each factor are provided, as well as an overall score for total EI; scores can be calculated based on expert or consensus criteria. In the present study, we used consensus criteria to calculate scores for each of the four factors and total EI. Scores are standardized $(M=100, S D=15)$. MSCEIT usually takes approximately 45-60 minutes to be completed. Reliability analyses of the MSCEIT with the standardisation sample suggested that the questionnaire has good internal consistency at the full-scale, area and factor level (Mayer, et al., 2003).

The SSEIT is a trait-based measure that evaluates how individuals are able to identify, understand and regulate emotions themselves and in others. The questionnaire is made up by 33 items that they should be answered by a Likert scale from 1 to 5 where 1 is strongly agree and 5 strongly disagree. SSEIT usually takes approximately 15-20 minutes to be completed. Reliability analyses of the SSEIT suggested that the questionnaire has good internal reliability, indicating that the scores were fairly stable over time (Schutte et al., 1998).

\section{Climbing ability performance}

Self-reported climbing ability was reported as the most difficult red-point (pre-practised) route completed without falls within the last 6-12 months. This method has been previously validated by (Draper et al., 2011). Climbing ability was converted to a standard numerical scale to enable calculations and statistical analyses according to (Draper et al., 2016). The sex-specific 75th percentile of red-point climbing ability was used to divide the sample into advanced $(\geq 75$ th $)$ and elite $(<75$ th) climbers for further analyses following the rationale of España-Romero et al., 2009.

\section{Data analysis}

All the variables showed a satisfactory pattern after studying their distribution using the Kolmogorov-Smirnov's test. The data are presented as mean and standard deviation (SD). Differences between male and female as well as expert and elite climbers in EI parameters in both questionnaires were analysed by one-way analysis of variance. The analyses were also adjusted by age using one-way analyses of co-variance (ANCOVA). Linear regression analyses were performed to examine the relationship between EI and gender as well as EI and climbing performance. Statistical analyses were performed using STATA version 14.0 (Stata Corp, College Station, TX, USA). Statistical significance was set at $p<0.05$.

\section{Results}

Red-point climbing ability in women ranged from $6 \mathrm{c}$ to $7 \mathrm{a}$ in advanced climbers $(\mathrm{n}=9)$, and from $7 \mathrm{a}+$ to $7 \mathrm{c}$ in elite climbers (75th percentile, $7 \mathrm{a}+, \mathrm{n}=6$ ). In men, climbing ability ranged from $6 b$ to $7 c$ in advanced climbers $(n=20)$, and from $7 c+$ to $8 b+$ in the elite group (75th percentile, $7 \mathrm{c}+, \mathrm{n}=8$ ).

MSCEIT scores are presented in Table 2. Significant differences were found for 'Facilitation Thought', Advanced climbers had a significantly higher measure of 'Facilitation Thought' compared to Elite climbers (110.4 \pm 10.6 vs. $102.9 \pm 11.8$, respectively). The same results were found when analyses were performed adjusted by age. 
Garrido-Palomino, I., \& España-Romero, V. (2019). Role of emotional intelligence on rock climbing performance. RICYDE. Revista internacional de ciencias del deporte. 57(15), 284-294.

Table 2. MSCEIT Scores Split by Sex and Climbing Ability

\begin{tabular}{|c|c|c|c|c|}
\hline & $\begin{array}{l}\text { Male } \\
(n=28)\end{array}$ & $\begin{array}{l}\text { Female } \\
(n=14)\end{array}$ & $\begin{array}{l}\text { Expert } \\
(n=27)\end{array}$ & $\begin{array}{l}\text { Elite } \\
(n=15)\end{array}$ \\
\hline Total score MSCEIT & $103.4 \pm 10.5$ & $107.5 \pm 10.4$ & $105.1 \pm 10.0$ & $104.4 \pm 11.8$ \\
\hline \multicolumn{5}{|l|}{ Areas } \\
\hline Experiential area & $104.3 \pm 11.0$ & $108.5 \pm 12.5$ & $107.1 \pm 11.8$ & $103.2 \pm 11.2$ \\
\hline Strategic area & $101.7 \pm 11.5$ & $104.1 \pm 8.0$ & $101.8 \pm 9.9$ & $103.9 \pm 11.7$ \\
\hline \multicolumn{5}{|l|}{ Aptitudes } \\
\hline Perceiving Emotions & $101.8 \pm 13.5$ & $107.6 \pm 14.1$ & $104.4 \pm 15.1$ & $102.6 \pm 11.5$ \\
\hline Facilitation Thought & $107.7 \pm 11.0$ & $107.5 \pm 12.7$ & $110.4 \pm 10.6$ & $102.9 \pm 11.8^{* \dagger}$ \\
\hline Understanding Emotions & $96.9 \pm 11.9$ & $96.9 \pm 7.6$ & $95.7 \pm 10.6$ & $99.1 \pm 10.7$ \\
\hline Managing Emotions & $107.5 \pm 10.4$ & $113.3 \pm 11.8$ & $110.0 \pm 10.7$ & $108.6 \pm 12.3$ \\
\hline
\end{tabular}

MSCEIT scores measured by the Mayer-Salovey-Caruso Emotional Intelligence Test.

* $\mathrm{P}<0.05$ differences between male and female or expert and elite climbers

$\dagger \mathrm{P}<0.05$ differences between male and female or expert and elite climbers adjusted by age

SSEIT scores are presented in Table 3. Skill 'Expression of Emotions' and 'Regulation of Emotions' were significantly higher in males than females $(55.6 \pm 5.2$ and $43.4 \pm 3.5$, respectively), however, the significance disappeared when adjusted for age.

Table 3. SSEIT Scores Split by Sex and Climbing Ability

\begin{tabular}{|c|c|c|c|c|}
\hline & $\begin{array}{c}\text { Male } \\
(n=27)\end{array}$ & $\begin{array}{c}\text { Female } \\
(n=14)\end{array}$ & $\begin{array}{l}\text { Expert } \\
(n=26)\end{array}$ & $\begin{array}{c}\text { Elite } \\
(n=15)\end{array}$ \\
\hline Total score SSEIT & $131.2 \pm 10.8$ & $126.4 \pm 11.1$ & $131.1 \pm 11.2$ & $126.7 \pm 10.4$ \\
\hline Expression of emotions & $55.6 \pm 5.2^{*}$ & $52.2 \pm 4.4$ & $55.6 \pm 5.3$ & $52.4 \pm 4.4$ \\
\hline Regulation of emotions & $43.4 \pm 3.5^{*}$ & $40.7 \pm 4.2$ & $42.8 \pm 4.1$ & $42.0 \pm 3.5$ \\
\hline Use of emotions & $32.0 \pm 4.3$ & $33.4 \pm 3.8$ & $32.6 \pm 3.3$ & $32.2 \pm 5.4$ \\
\hline
\end{tabular}

Linear regression analyses adjusted for age revealed that 'Facilitation Thought' was inversely associated with the highest red-point ability ( $\beta$ :-7.04 and 95\% CI: -14.19 to $-0.10 ; p<0.05$ ). The percentage of variance $\left(\mathrm{R}^{2}\right)$ explained by self-reported grade was $14.5 \%$ (Figure 1 ). 
Garrido-Palomino, I., \& España-Romero, V. (2019). Role of emotional intelligence on rock climbing performance. RICYDE. Revista internacional de ciencias del deporte. 57(15), 284-294.

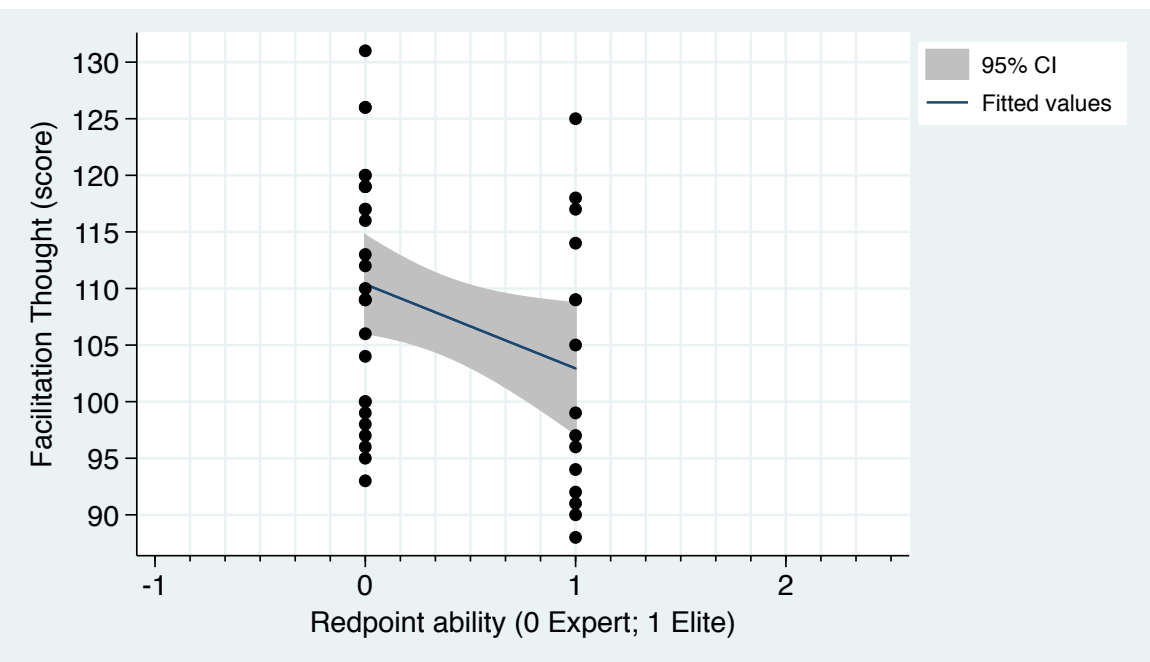

Figure 1. Linear regression analyses between 'Facilitation Thought' and redpoint ability categories adjusted by age

\section{Discussion}

Some authors speculate that EI could influence in athletes because they are better able to perceive, monitor, use, and manage emotions in response to competition stress and use more effective coping strategies in response to the emotions (Crombie et al., 2009; Zizzi et al., 2003). This position supports the idea that higher levels of EI could help to reach higher levels of sport performance.

Given emotions could have negative effects in sport climbing (Green, Draper \& Helton, 2014), we might think that EI had a relationship with climbing performance. The main finding of this study was that elite climbers presented lower scores compared to advanced climbers for an EI component, i.e., 'Facilitation Thought', when it was assessed by the MSCEIT questionnaire. Differences between EI and climbing performance were not observed when EI was assessed using the SSEIT questionnaire. While literature on emotional intelligence argues the use of emotions as a facilitator to improve sports performance, since participants could take advantage of these emotions in the use of certain cognitive practices, such as reasoning, problem-solving, decision making and interpersonal communication (Brackett \& Salovey, 2006), we observed contrary results in sport climbers. Therefore, the results observed in this study show that high and low EI scores may differentiate ability groups of climbers and may be an important factor for climbing performance. However, it is necessary to understand those differences in our results are likely due to different approaches of emotional intelligence, since ability approach of emotional intelligence, assessed by MSCEIT questionnaire, which is a range that could be modify by training. Whereas trait approach of emotional intelligence, measured by SSEIT, which are aspects of personality that are relatively stable over time.

The current study suggests that the ability construct 'Facilitation Thought' is related to climbing performance. Although we hypothesized a priori that elite climbers would exhibit higher emotional intelligence scores, the differences were in the opposite direction to what we expected. The relationship observed between 'Facilitation Thought' and sport performance could suggest that higher scores in this component could be a disadvantage to climbing performance. In an effort to understand the observed negative relationship between 'Facilitation Thought' and climbing performance, a number of reasons may be offered to explain why elite climbers have a lower EI score, and why this may be advantageous. 
Garrido-Palomino, I., \& España-Romero, V. (2019). Role of emotional intelligence on rock climbing performance. RICYDE. Revista internacional de ciencias del deporte. 57(15), 284-294.

https://doi.org/10.5232/ricyde2019.05706

'Facilitation Thought' refers how emotions may be used in different situations and how they may be associated with sensations to facilitating of thought and then allowing emotions to direct attention. In sport psychology, anxiety is generally accepted as an unpleasant emotion likely to arise when individuals doubt their ability to cope with external or internal demands (Woodman \& Hardy, 2003). Anxiety has an important presence in sport climbing and it has been observed that detrimentally affect performance in climbers (Green et al., 2014; Nieuwenhuys et al., 2008; Pijpers et al., 2005). However, it is possible that climbers with higher levels of 'Facilitation Thought' could perceive an increase in anxiety, caused by emotions present in sport climbing as fear or threat. As a result of this fear or threat, there may be a disruption in performance which may occur as a result of either attention being focused on the emotions rather than the task (distraction), and/or conscious monitoring of the movement and technique (conscious processing) ( Nieuwenhuys \& Oudejans, 2012).

Another potential reason for performance disruption may be that climbers with higher levels of 'Facilitation Thought' are more susceptible to experiencing negative emotions because of the characteristics of the demands of rock climbing. For example, the distance between points of protection on a route, a fear of failure or a fear of falling (Draper et al., 2012; Draper, Jones, Fryer, Hodgson, \& Blackwell, 2010; Draper, Jones, Fryer, Hodgson, \& Blackwell, 2008). Additionally, 'Facilitation Thought' could facilitate an attention focus on emotions by causing cognitive interference within the climber (McCarthy, Allen, \& Jones, 2013) or by consuming cognitive resources necessary for motor planning or by altering the climber's focus of attention (Green et al., 2014). This would mean they become distracted by the anguish generated by different types of fear (fear of failure or fear of falling) causing decrements in performance on tasks, according to Green et al. (2014). Therefore, it could be possible that a low score on these components of EI, allows elite rock climbers not to interact with those emotions, that negatively interfering with their limited attentional resources. Additionally, we suggest it could be possible that elite climbers had attentional superiority on skill-related rock climbing, that prevent negative emotional interferences that act as a strong distractor as expose He et al. (2018) in a EEG research with tennis players .

The current study is the first known investigation, which analyses EI as an ability and as a trait in a non-group/team based sport. Previously, while EI as trait has also been assessed in individual athletes (Chakarvarti \& Lal, 2016) to our knowledge EI has only been measured as an ability in team sports (Crombie et al., 2009; Crombie et al., 2011; Laborde et al., 2015). When assessed as a trait using the SSEIT, Chakarvarti \& Lal, (2016) observed contradictory results to ours, with significant differences for EI, as a trait, in 15 individual athletes categorized at the high-performance group compared to the 8 athletes categorised at the low performance group. The differences in our results could be attributed to different sporting contexts, demands or performances promote the development of different psychological skills or cognitive-emotional functioning (sprinters against climbers) (Schmidt \& Wrisberg, 2008). As suggested by Taylor, (1995) each sport has special physical, technical and psychological characteristics which requires specific mental abilities for its practicing athletes, what can make sense of these differences in our results.

Although various authors have repeatedly suggested that variables of a psychological nature may be crucial to successful climbing performance (Espana-Romero et al., 2012; Watts, 2004), this study is the first study exploring the relationship between EI and climbing performance and the first with ability measures in an individual sport. Whilst this was the first study of its type in rock climbers, and there are several strengths such as 1) unique access to a highly skilled group of elite climbers, and 2) we used two types' questionnaires to determine EI, there are some limitations that should be recognised. The main limitation concerns the 
Garrido-Palomino, I., \& España-Romero, V. (2019). Role of emotional intelligence on rock climbing performance. RICYDE. Revista internacional de ciencias del deporte. 57(15), 284-294.

sample size. Although the experiment offers statistically significant results, the sample size is small, which causes the study to have low statistical power (53.2\%). Moreover, the unresolved issues related the controversy in the construct of EI have implications for researchers and those in professional practice seeking to understand its influence on sports performance (Laborde et al., 2015). Future research should look to examine possible presence or interactions between EI and other variables that may influence climbing performance such as positive affect (Sanchez et al., 2010), self-confidence (Woodman \& Hardy, 2003) or attentional resources (Sanchez-Lopez, Silva-Pereyra, \& Fernandez, 2016; Taylor, 1995).

\section{Conclusion}

In conclusion, the results of this study suggest that elite climbers have lower ability EI component score of 'Facilitation Thought' compared to advanced climbers when measured as ability but not trait-based measure. These suggest that there is an ability related with the use of emotions to facilitating thoughts linked with differences in climbing performance; further the results imply differences in emotional functioning advantageous for the greatest ability climbers. Rock climbers and coaches should develop a specific training in mental toughness or psychological skills direct to regulating and managing emotions in less experienced climbers. Our findings highlight the needed to consider the influence of other psychological factors upon sport climbing performance that differentiates between elite and expert climbers. Future research should be direct to investigate how emotions affect experts and elite climbers, and how emotions are managed by both types of climbers.

\section{References}

Aras, D., \& Akalan, C. (2014). The effect of anxiety about falling on selected physiological parameters with different rope protocols in sport rock climbing. Journal of Sports Medicine and Physical Fitness, 54(1), 1-8. Retrieved from:

http://www.ncbi.nlm.nih.gov/pubmed/24445539

Bourdin, C.; Teasdale, N., \& Nougier, V. (1998). Attentional demands and the organization of reaching movements in rock climbing. Research Quarterly for Exercise and Sport, 69(4), 406-410. Retrieved from:

http://www.ncbi.nlm.nih.gov/pubmed/9864759

Brackett, M. A., \& Salovey, P. (2006). Measuring emotional intelligence with the MayerSalovery-Caruso Emotional Intelligence Test (MSCEIT). Psicothema, 18 Suppl, 34-41.

Calvo, M. G., \& Eysenck, M. W. (1992). Anxiety and Performance: The Processing Efficiency Theory. Cognition and Emotion, 6(6), 409-434. https://doi.org/10.1080/02699939208409696

Crombie, D.; Lombard, C., \& Noakes, T. (2011). Increasing Emotional Intelligence in Cricketers: An Intervention Study. International Journal of Sports Science \& Coaching, 6(1), 69-86.

https://doi.org/10.1260/1747-9541.6.1.69

Crombie, D.; Lombard, C.; Noakes, T.; Crombie, D.; Lombard, C., \& Noakes, T. (2009). Emotional Intelligence Scores Predict Team Sports Performance in a National Cricket Competition. International Journal of Sports Science \& Coaching 4(2), 209-224.

Draper, N.; Dickson, T.; Blackwell, G.; Fryer, S.; Priestley, S.; Winter, D., \& Ellis, G. (2011). Self-reported ability assessment in rock climbing. Journal of Sports Sciences, 29(8), 851-858.

https://doi.org/10.1080/02640414.2011.565362 
Garrido-Palomino, I., \& España-Romero, V. (2019). Role of emotional intelligence on rock climbing performance. RICYDE. Revista internacional de ciencias del deporte. 57(15), 284-294.

https://doi.org/10.5232/ricyde2019.05706

Draper, N.; Dickson, T.; Fryer, S.; Blackwell, G.; Winter, D.; Scarrott, C., \& Ellis, G. (2012). Plasma cortisol concentrations and perceived anxiety in response to on-sight rock climbing. International Journal of Sports Medicine, 33(1), 13-17.

https://doi.org/10.1055/s-0031-1284348

Draper, N.; Giles, D.; Schöffl, V.; Konstantin Fuss, F.; Watts, P.; Wolf, P.; ... Abreu, E. (2016). Comparative grading scales, statistical analyses, climber descriptors and ability grouping: International Rock Climbing Research Association position statement. Sports Technology, 8(3-4), 88-94.

https://doi.org/10.1080/19346182.2015.1107081

Draper, N.; Jones, G. A.; Fryer, S.; Hodgson, C., \& Blackwell, G. (2008). Effect of an onsight lead on the physiological and psychological responses to rock climbing. Journal of Sports Science \& Medicine, 7(4), 492-498.

Draper, N.; Jones, G. A.; Fryer, S.; Hodgson, C. I., \& Blackwell, G. (2010). Physiological and psychological responses to lead and top rope climbing for intermediate rock climbers. European Journal of Sport Science, 10(1), 13-20. https://doi.org/10.1080/17461390903108125

España-Romero, V.; Artero, E. G.; Ortega, F. B.; Jiménez-Pavón, D.; Gutiérrez, A.; Castillo, M. J., \& Ruiz, J. R. (2009). Physiology of sport climbing. Revista Internacional de Medicina y Ciencias de La Actividad Física y Del Deporte, 9(35), 264-298.

España-Romero, V., Ruiz, J. R., Ortega, F. B., Artero, E. G., Vicente-Rodríguez, G.; Moreno, L. A., ... Gutierrez, A. (2009). Body fat measurement in elite sport climbers: Comparison of skinfold thickness equations with dual energy X-ray absorptiometry. Journal of Sports Sciences, 27(5), 469-477.

https://doi.org/10.1080/02640410802603863

España-Romero, V.; Ortega-Porcel, F. B.; Artero, E. G.; Jiménez-Pavón, D.; Gutiérrez Sainz, A.; Castillo-Garzón, M. J., \& Ruiz, J. R. (2011). Climbing time to exhaustion is a determinant of climbing performance in high-level sport climbers. European Journal of Applied Physiology, 107(5), 517-25.

https://doi.org/10.1007/s00421-009-1155-x

España-Romero, V.; Jensen, R. L.; Sanchez, X.; Ostrowski, M. L.; Szekely, J. E., \& Watts, P. B. (2012). Physiological responses in rock climbing with repeated ascents over a 10-week period. European Journal of Applied Physiology, 112(3), 821-828. https://doi.org/10.1007/s00421-011-2022-0

Green, A., \& Helton, W. (2011). Dual-task performance during a climbing traverse. Experimental Brain Research, 215(3), 307-313.

https://doi.org/10.1007/s00221-011-2898-2

Green, A. L.; Draper, N., \& Helton, W. S. (2014). The impact of fear words in a secondary task on complex motor performance: A dual-task climbing study. Psychological Research, 78(4), 557-565.

https://doi.org/10.1007/s00426-013-0506-8

Hardy, L., \& Hutchinson, A. (2007). Effects of performance anxiety on effort and performance in rock climbing: a test of processing efficiency theory. Anxiety, Stress, and Coping, 20(2), 147-161.

https://doi.org/10.1080/10615800701217035

Hardy, L., \& Jackson, B. (1996). Effect of state anxiety upon effort and performance in rock climbers. Journal of Sports Sciences, 14(1), 31-32.

Hodgson, C. I.; Draper, N.; McMorris, T.; Jones, G.; Fryer, S., \& Coleman, I. (2009). Perceived anxiety and plasma cortisol concentrations following rock climbing with differing safety rope protocols. British Journal of Sports Medicine, 43(7), 531-535. https://doi.org/10.1136/bjsm.2007.046011 
Garrido-Palomino, I., \& España-Romero, V. (2019). Role of emotional intelligence on rock climbing performance. RICYDE. Revista internacional de ciencias del deporte. 57(15), 284-294.

Laborde, S.; Dosseville, F., \& Allen, M. S. (2015). Emotional intelligence in sport and exercise: A systematic review. Scandinavian Journal of Medicine \& Science in Sports, 26(8), 862-874.

https://doi.org/10.1111/sms.12510

Mayer, J. D. \& Salovey, P. (1997). What is emotional intelligence? In D. Sluyter (Ed.), Emotional development and emotional intelligence: educational implications. (pp. 331). NewYork. Retrieved from: http://catalog.hathitrust.org/Record/003165342

Mayer, J. D.; Salovey, P.; Caruso, D. R., \& Sitarenios, G. (2003). Measuring Emotional Intelligence with the MSCEIT V2.0. Emotion, 3(1), 97-105. https://doi.org/10.1037/1528-3542.3.1.97

McCarthy, P. J.; Allen, M. S., \& Jones, M. V. (2013). Emotions, cognitive interference, and concentration disruption in youth sport. Journal of Sports Sciences, 31(5), 505515. https://doi.org/10.1080/02640414.2012.738303

Nieuwenhuys, A., \& Oudejans, R. R. D. (2012). Anxiety and perceptual-motor performance: Toward an integrated model of concepts, mechanisms, and processes. Psychological Research, 76(6), 747-759. https://doi.org/10.1007/s00426-011-0384-x

Nieuwenhuys, A.; Pijpers, J. R.; Oudejans, R. R. D., \& Bakker, F. C. (2008). The influence of anxiety on visual attention in climbing. Journal of Sport \& Exercise Psychology, 30(2), 171. Retrieved from: http://www.ncbi.nlm.nih.gov/pubmed/18490789

Pijpers, J. R.; Oudejans, R. R. D., \& Bakker, F. C. (2005). Anxiety-induced changes in movement behaviour during the execution of a complex whole-body task. The Quarterly Journal of Experimental Psychology Section A, 58(3), 421-445. https://doi.org/10.1080/02724980343000945

Robazza, C.; Bortoli, L., \& Nougier, V. (1998). Performance-related emotions in skilled athletes: hedonic tone and functional impact. Perceptual and Motor Skills, 87(2), 547564. https://doi.org/10.2466/pms.1998.87.2.547

Salovey, P., \& Mayer, J. D. (1990). Emotional Intelligence. Imagination, Cognition and Personality, 9(3), 185-211.

https://doi.org/10.2190/DUGG-P24E-52WK-6CDG

Sánchez-Lopez, J.; Silva-Pereyra, J., \& Fernandez, T. (2016). Sustained attention in skilled and novice martial arts athletes: a study of event-related potentials and current sources. Peer J, 4, 1-23.

https://doi.org/10.7717/peerj.1614

Sánchez, X.; Boschker, M. S. J., \& Llewellyn, D. J. (2010). Pre-performance psychological states and performance in an elite climbing competition. Scandinavian Journal of Medicine and Science in Sports, 20(2), 356-363.

https://doi.org/10.1111/j.1600-0838.2009.00904.x

Schutte, N. S.; Malouff, J. M.; Hall, L. E.; Haggerty, D. J.; Cooper, J. T.; Golden, C. J., \& Dornheim, L. (1998). Development and validation of a measure of emotional intelligence. Personality and Individual Differences, 25(2), 167-177. https://doi.org/10.1016/S0191-8869(98)00001-4

Taylor, J. (1995). A Conceptual Model for Integrating Athletes' Needs and Sport Demands in the Development of Competitive Mental Preparation Strategies. The Sport Psychologist, 9(3), 339-357.

https://doi.org/10.1123/tsp.9.3.339 
Garrido-Palomino, I., \& España-Romero, V. (2019). Role of emotional intelligence on rock climbing performance. RICYDE. Revista internacional de ciencias del deporte. 57(15), 284-294.

Watts, P. B. (2004). Physiology of difficult rock climbing. European Journal of Applied Physiology, 91(4), 361-372.

https://doi.org/10.1007/s00421-003-1036-7

Woodman, T., \& Hardy, L. (2003). The relative impact of cognitive anxiety and selfconfidence upon sport performance: a meta-analysis. Journal of Sports Sciencies, 21(42), 443-457.

https://doi.org/10.1080/0264041031000101809

Zizzi, S.; Deaner, H., \& Hirschhorn, D. (2003). The Relationship Between Emotional Intelligence and Performance Among College Basketball Players. Journal of Applied Sport Psychology, 15(3), 262-269.

https://doi.org/10.1080/10413200390213371 